\title{
ネパール国立古文書館所蔵『デーヴィーマー ハートミヤ絵図』に夕られる女神の図像的特徵
}

\section{森喜子}

I 、『デーヴィーマーハートミヤ (女神の偉大さ)』Devimāhātmya (DM) は, ヒンドゥー教の女神信仰に括いて最も重要な聖典の1つで，そこにあらわれる女 神の姿は古くから多くの䧓像や絵画に表されてきた。カトマンドゥにあるネパー ルの国立古文書館 (National Archives) 所蔵の『デーヴィーマーハートミヤ絵図』 (Citramaya candi saptaśatiko, Ms. No. Ca. 2422, Sub. No. 30)1) は125枚の彩色画 で構成され，「ka. 1」と記された 1 枚を除く 124 枚の画面にデーヴァナーガリー で1から 124 の番号が付されている。No. 124 はこの絵図と関係があ゙ったと考兄 られる一家の肖像で, Nos. 11-117，119-123 に DM の女神神話が描かれる。 Nos. 1-10, No. 118 には女神が 1 枚に 1 人ずつ描かれるが，名称などの記述も なくDMの神話の中には対応籄所が見られない。ここではこの絵図中の女神の図 像的特徵を整理し，文献資料にみられる女神の記述との比較を試みる。

II . 絵図にみられる女神の図像的特徵

(1) DMの神話は 3 つのエピソードから構成される。絵図中の第 1 エピソードを 示す部分では, 剣, 楯, 杯, 施無畏印を示した女神がヴィシュ又の体から生じた 場面が No. 18 に描かれる。第 2 エピソードの水牛の魔神を殺す女神は16臂で数 珠, 水瓶, 剣, 蓮華, 杖, 弓, 羉索, 鉤, 円盤, 泀ら貝, 槍, 矢, 金剛杵, 金剛 鈴, どくろ杖などを持ち，身色は赤である。

第 3 エピソードには数多くの女神が出現する。シュンバとニシュンバを殺す女 神は, 8 臂で, 弓, ほら貝, 鉤, 蓮華, 矢, 円盤, 杵, 羂索を持つが, 場面によ っていずれかが三叉戟や施無畏印に変わったりする。身色は白である。この女神 を助ける $\mathrm{Ka}$ li $\bar{i}$ 女神は身色は青で, 剣, 縝索, 楯, がい骨をもつ。また七母神 Saptamātṛkā はいずれも 4 臂で，それぞれが夫である神々と同様の持物や乗り 物をもつ。シュンバとニシュンバを殺す女神の力 śakti の具現である Caṇdikāśakti は16臂で, 鉤, 蓮華, ほら貝, 杖, 羅索, 三叉戟, 金剛杵, どくろ杖, 槍, 矢, 弓を持ち, ジャッカルの群れをしたがえる。第 3 エピソードの最後には, 王 
と商人の前に女神が出現し，願いをかなえる。その女神は No. 120 に身色が赤で 4 臂に羂索，矢，鉤，弓を持つ姿で描かれる。

(2)Nos. 1-10,118 にみられる女神の図像的特徴は次のと拉りである。

No. 1 の女神は身色は青で10臂, 右手に剣, 杖, 弓, 三叉戟, 人頭を持ら, 左 手に円盤, 矢, 杖, ブーメラン(?)，㴗貝を持つ。左足の部分は破損している が右に 5 本の足があり, 左上部以外に九面が確認でき，十面十足をるつと考兄ら れる。No. 2 の女神は身色は赤で 18 臂, 右手飞羂索, 杯, 泀ら貝, 剣, ぞくろ 杖, 弓, 金剛杵, 杖, 数珠を持ち, 左手に円盤, 三叉戟, 金剛鈴, 楯, 短剣, 三 叉棒, 蓮華, 矢, 斧を持つ。No. 3 の女神は白で 8 臂, 右手に弓, 杵, 鉤, 鈴を もち, 左手に矢, 円盤, 注ら貝, 三叉戟を持つ。No. 4 は赤で 4 臂, 数珠, 与願 印を右手で示し，左手で経函と施無畏印を示す。No. 5 は黒で 4 臂，右手で楯と ほら貝をもち，左手で剣と円艋を持つ。No. 6 は灰色で 4 臂，両手でヴィーナを 持ち, 右手でほら貝, 左手で杯を持つ。No. 7 は赤で 4 臂, 右手で縎索と蓮華を 持ち, 左手で鉤と弓を持つ。No. 8 は赤で 4 臂, 右手で与願印と羉索を示し, 左 手で弓と銁を持つ。No. 9 は赫で 4 臂, 右手で羉索, 弓を持ら, 左手で鉤と矢を 持つ。No. 10 は赤で 4 臂，右手で弓，注ら貝を持ち，左手で矢，円盤を持つ。 No. 118 は赤で 6 臂, 右手に円盤, 剣, 棒を持ら, 左手で杖, ブーメラン(?), 弓を持ち，剣と楯を持つ 4 人の女性を従える。

III. 文献にみられる女神の図像的特徴と絵図の女神

(1)DMの第 1 エピソードでは，女神をヴィシュヌの体から出現させるため，ブ ラフマーが女神への讃歌を唱觉る。DMの第1章第 61 偈 (DM I . 61) では女神 は「剣，三叉戟，杖，円盤，ほら貝，矢，弓，鉄棒，ブシュンディーをもつ」と され，絵図中の第 1 エピソードの女神とは一致しない。

第 2 エピソードでは神々の発した光線から女神が出現する場面で (DM II. 19 -31)，神々が贈った品々として，三叉戟，円盤，ほら貝，シャクティ，矢，弓， 金剛杵，鈴，カーラダンダ，羉索，数珠，水瓶，笑，杯，蓮華などが述べられ， 絵図中の第 2 エピソードの女神の持物はこれらとほぼ一致する。

第 3 エピソードの中心となる女神に関しては文献にその姿のまとまった記述は ないが，戦いの中で「剣，弓，矢」「戟，金剛杵，剣，楯」「ほら貝，鈴」を用い たとされる (DM VII. 30,60，IX.17etc.)。これらは絵図中の女神の持物に含まれる が, 絵図の女神が持つ杵, 羂索, 鉤なぞの記述は文献にはない。カーリー, 七母 神の文献中の記述と絵図はほぼ一致する2゙。チャンディカーシャクティの姿の具 
（70） ネパール国立古文書館所蔵『デーヴィーマーハートミヤ絵図』(森) 体的な記述はDMにはみられない33。

(2)DMに付随した瞑想法との比較

DMは『マールカンデーヤプラーナ』Mārkaṇdeyapurāna の一部ではあるが, 『サプタシャティー』Saptaśatĩ,『チャンディー』Candīなどの表題で独立した 書物として扱われることも多い。その場合プラーナに含まれる神話 (全13章)の 部分に加えて，女神への讃歌，瞋想法 (dhyāna), 儀礼の手順などが付加される。 瞑想法はDMの三つのエピソードの前（第 1 章，第 2 章，第 5 章の前）におかれる 場合や，DMの13章の各々の前に和かれる場合がある4”。三つのエピソードの前 の瞑想法に描かれる女神の姿は次のと和りである。

1 Mahākālikā 女神。身色は青で十面十足, 剣, 円盤, 杖, 弓, 鉄棒, 三叉戟, ブシ ニンディ, 人頭, ほら貝を手に持つ。

2 Mahālakșmī 女神。数珠, 斧, 杖, 矢, 金剛杵, 蓮華, 弓, 水瓶, シャクティ, 剣, 楯, 涼ら貝, 鈴, 酒器, 三叉戟, 円盤を持ち, 身色はさんご色。

3. Sarasvatī 女神。鈴, 戟, 鋸, 活ら貝, 杵, 円盤, 弓, 剣を持つ。

これらの記述と絵図の Nos. 1-3 の女神の姿を比較すると，持物，臂数など多 くの点で一致する。これらの瞑想法は Bhāskararaya のDMに対する注釈にも見 られる5゙。またDMに付属したアンガ (anga，部分) と呼ばれる文献の1つにVaikrtika Rahasya があるが，そこにも Mahākālī, Mahālakșmī, Sarasvatĩ の姿 の記述がある6)。その記述と三つの瞋想法を比べると，表現は異なるが，持物等 は一致する。さらに『デーヴィーバーガヴァタプラーナ』Devībhāgavatapurāna 第 9 巻50章65-72偈にある女神の顛想法との間にも多くの一致がみられる。

瞑想法が13ある各章の前に预かれる場合，多くの版では先述した三つの瞑想法 が第 1 章，第 2 章，第 5 章の前にある。第 3 章に Jagadambā，第 4 章に Jayā, 第 6 章に Padmāvatì, 第 7 章に Mātangī, 第 8 章に Bhavanī, 第 9 章に Ambikeśa，第10章に Kāmeśvarī, 第11章に Bhuvaneśī, 第12章に Durgā, 第13章に Sivā の瞑想法がある。一方, Bharany によって18 世紀のパハリ一画に拉ける DMの瞑想法と図版が発表されている7)。そこでは第 5 章に Durgā，第 6 章に Sarasvatī，第 8 章に Padmāvatī が特かれ，他にみられる Bhavanī がない。第 5 章の Durgā の瞑想法は他にみられない。

この13の睻想法と絵図を比較すると，No. 3 の女神は第 3 章の Jagadambā, No. 5 は第 7 章の Mātañgi, No. 9 は第 8 章の Bhavanī 又は Bharany 版の第 13章の Sivā, No. 10 は Bharany 版の第 5 章の Durgā に一致する。No. 5 と 
ネパール国立古文書館所蔵『デーヴィーマーハートミヤ絵図』(森)

第 4 章の Jayā, No. 118 と第12章の Durgā も一致する点が多い。

N. この絵図で神話を表した部分以外の図版に描かれた女神はDMに付敄られ た睻想法と関連があり, Nos. 1-3 は Mahākālikā, Mahālakṣmīi, Sarasvatī を 示すと考觉られる。これらの瞑想法の起源は明らかではないが, Mahākāli は本 稿四の(1)で述べた DM I. 61 の女神の記述に近く, Mahālakșmī は第 2 エピソ ードで神々が女神に贈った武器等を持物として持つ。

絵図中の神話部分とそれ以外の女神を比較すると, 第 2 エピソードの水牛の魔 神を殺す女神と No. 2 の女神，また第 3 エピソードのシュンバとニシュシバを 殺す女神と No. 3 の女神には一致ずる点が多い。これはNo. 2 と No. 3 の女 神が第 2 , 第 3 のエピソードの前の瞑想法の女神を示すことと関連があると考光 られる。また神話部分の第 13 章にあらわれる女神は No. 9 の女神に一致し, No. 9 の女神は Bharany 版の第 13 章の瞑想法の女神の姿と一致する。

このようにこの絵図の女神の図像的特徽はDMの神話のみではなく, 睻想法な ぞの文献とも関連があり，DMの神話や女神を造形作品に表す際にDMに付けら れた神話以外の文献も重要な役割を持っていたことを示すと考兄られる。

1）この絵図の概要については拙稿「ネパール国立古文書館所蔵『デーヴィーマーハー トミヤ絵図』」『東海仏教』第36輯, 1991, pp. 99-89 参照。

2）カーリーについては DM VII. 5-7。文献に khaṭāinga（どくろ杖）とあるが, 絵図 ではがい骨を持つ。七母神については VIII. 11-20。

3）絵図にジャッカルが描かれるのは DM VIII. 20.「百匹のジャッカルのように㭈える」 VIII. 26.「(魔神の) 肉で私のジャッカルを満足させる」等を表現したと考えられる。

4）前者に Nirnayasagara Press 版や Ramakrșṇa Math 版などがあり，後者に Gītā Press 版, Jaya Nepal Prakasam 版などぶある。

5) Durgãsaptaśatī with Seven Commentaries, Delhi, 1984, p. 13.

6) Vaikrtika Rahasya 2-5, 11-16. 他に anga として Kavaca, Argalā, Kïlaka, Prādhānika Rahasya, Mūrti Rahasya などがあげられる。

7) C. Bharany, Images of Devi in Pahari Paintings. New Delhi, 1984.

〈キーワード〉 Devīmāhātmya，瞑想法，女神信仰 